\title{
Spinal Vascular Shunts: A Patterned Approach
}

\author{
(D) M.P. Kona, (D) K. Buch, (D). Singh, and (D) S. Rohatgi
}

\begin{abstract}
SUMMARY: Spinal vascular shunts, including fistulas and malformations, are rare and complex vascular lesions for which multiple classification schemes have been proposed. The most widely adopted scheme consists of 4 types: type I, dural AVFs; type II, intramedullary glomus AVMs; type III, juvenile/metameric AVMs; and type IV, intradural perimedullary AVFs. MR imaging and angiography techniques permit detailed assessment of spinal arteriovenous shunts, though DSA is the criterion standard for delineating vascular anatomy and treatment planning. Diagnosis is almost exclusively based on imaging, and features often mimic more common pathologies. The radiologist's recognition of spinal vascular shunts may improve outcomes because patients may benefit from early intervention.
\end{abstract}

ABBREVIATIONS: ASA = anterior spinal artery; $C S=$ classification scheme; IPAVF = intradural perimedullary arteriovenous fistula; PSA = posterior spinal artery; SDAVF = spinal dural arteriovenous fistula; SGAVM = spinal "glomus" arteriovenous malformation; SJAVM = spinal juvenile (metameric) arteriovenous malformation; SVS = spinal vascular shunt

$\mathbf{S}$ pinal vascular shunts (SVSs) including arteriovenous fistulas (AVFs) and malformations (AVMs) are rare lesions accounting for $3 \%-4 \%$ of intradural spinal lesions. ${ }^{1-4}$ The SVS presents a challenge from both an imaging and management perspective. Since the first SVS classification scheme (CS) was proposed in 1971 by Di Chiro et $\mathrm{al},{ }^{5}$ physicians from various specialties have proposed CSs on the basis of anatomy and/or management considerations typically relevant to the authors' fields of expertise. ${ }^{5-10}$ The current, most widely referenced CS is derived from the works of multiple authors. ${ }^{5-8}$ This article offers a review of the commonly referenced historic classification schemes, clinical symptomology, imaging findings, differential diagnoses, and management considerations.

\section{Normal Spinal Vascular Anatomy}

The cord is supplied by intramedullary sulcal branches of the anterior spinal artery (ASA) and radial perforators from the pial-

Received March 21, 2021; accepted after revision June 29.

From the Division of Neuroradiology (M.P.K.), Department of Radiology, Hunter Holmes McGuire VA Medical Center, Richmond, Virginia; Division of Neuroradiology (K.B.), Department of Radiology, Massachusetts General Hospital, Harvard Medical School, Boston, Massachusetts; and Division of Neuroradiology (I.S., S.R.), Department of Radiology, University of Massachusetts Medical School, Worcester, Massachusetts. Paper previously presented, in part, as an educational poster in a short digital format at: Annual Meeting of the European Congress of Radiology, July 15-19, 2020; Virtual.

Please address correspondence to Matthew P. Kona, MD, Division of Neuroradiology, Department of Radiology, Hunter Homes McGuire VA Medical Center, 1201 Broad Rock Blvd, Richmond, VA 23249; e-mail: mpkona@gmail.com

- Indicates open access to non-subscribers at www.ajnr.org

http://dx.doi.org/10.3174/ajnr.A7312 based vasacorona (Fig 1). ${ }^{11}$ The ASA and paired posterior spinal arteries (PSAs) originate from the intradural vertebral arteries and sometimes the posterior inferior cerebellar arteries. The ASA, PSA, and vasocorona receive collateral flow from approximately 7 or 8 medullary arteries, which share a common origin with the radicular and dural arteries supplying the nerve roots and dural sleeves. These radiculomedullary arteries arise from ventral spinal branches of segmental arteries. The well-known radiculomedullaris magna artery of Adamkiewicz provides collateral flow to the thoracolumbar cord, typically arising on the left between $\mathrm{T} 9$ and $\mathrm{T} 12 .^{2}$

Normal spinal venous anatomy grossly mirrors that of the arterial counterpart, with single anterior and dual posterior spinal veins coursing through a pial surface plexus. Medullary and radicular veins drain via transdural emissaries to intervertebral, longitudinal efferent, and other level-specific venous channels. ${ }^{4}$

\section{Historical Classification Schemes}

Various proposed SVS CSs have been historically based on anatomic, management, prognostic, or other considerations relevant to the authors' fields of expertise (Table 1). ${ }^{5,9}$ Modified versions of earlier SVS CSs have also challenged the scope of included lesions and/or degrees of subclassification. ${ }^{6-8,10}$ Although no proposal has been universally adopted, the recent emergence of a composite CS appears to seek a compromise. ${ }^{3,12-19}$ At the time of this publication, the most widely referenced CS reflects the contributions of multiple authors, beginning with types I-III of Di 

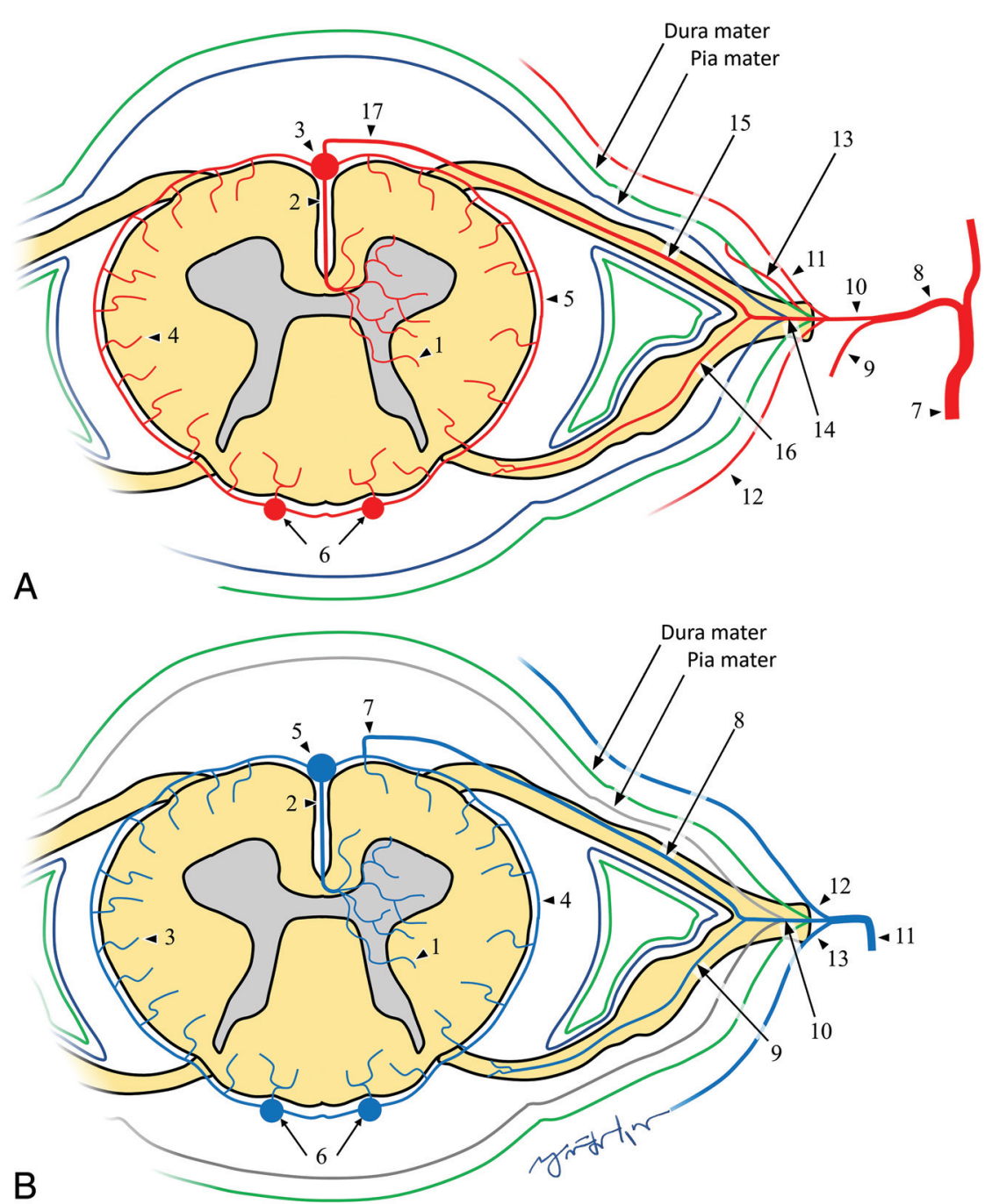

FIG 1. A, Normal arterial anatomy: 1, intramedullary branches; 2 , sulcal artery; 3 , anterior spinal artery; 4, radial perforators; 5 , pial arterial plexus; 6 , posterior spinal arteries; 7 , segmental artery; 8 , spinal artery; 9 , dorsal branch of the dorsospinal artery; 10 , ventral branch of dorsospinal artery; 11 , ventral epidural plexus; 12, dorsal epidural plexus; 13, dural artery; 14, radicular artery; 15, ventral radicular artery; 16, dorsal radicular artery; 17, medullary artery. B, Normal venous anatomy: 1, Intramedullary veins; 2 , sulcal vein; 3 , radial veins; 4 , pial venous plexus; 5 , anterior spinal vein; 6 , posterior spinal veins; 7 , medullary vein; 8 , ventral radicular vein; 9 , dorsal radicular vein; 10, emissary vein; 11, intervertebral vein; 12, branches from ventral epidural venous plexus; 13 , branches from dorsal epidural venous plexus. an intervening capillary network. Drainage is typically retrograde via a medullary vein and the pial venous network. $^{13,20,21}$ SDAVFs are slow-flow lesions, mostly acquired, possibly related to chronic fibrosis and/or venous thrombosis., ${ }^{1,18}$ Arterial flow is transferred to engorged venous collaterals, producing the angiographic "single coiled vessel" appearance. ${ }^{5}$

Type II: Spinal Glomus AVM. Type II spinal "glomus" arteriovenous malformations (SGAVMs) account for 19\%$45 \%$ of all SVSs. SGAVMs are congenital, high-flow lesions that may be thoracic (51\%), cervical (29\%), or lumbar/ conus (20\%) (Fig 2B). ${ }^{1,12,17,22}$ From a morphologic perspective, Di Chiro et $\mathrm{al}^{5}$ distinguished SGAVMs from SDAVFs by the presence of a "localized vascular plexus confined to a short cord segment." This intramedullary and/or pial-based nidus of abnormal vascular channels may be supplied by $\geq 1$ branch of the ASA, PSA, vertebral arteries, dural arteries, and/or vasocorona. ${ }^{23}$

Type III: Spinal Juvenile AVM. Type III spinal juvenile (metameric) arteriovenous malformations (SJAVMs) are the least common ${ }^{3,12}$ type of SVS, with estimated frequencies between 5.4\% and $9 \%$. Most cases involve the thoracic spine, followed by the cervical spine (Fig 2C). ${ }^{16,24}$

These voluminous, ${ }^{5}$ high-flow lesions are sometimes characterized as possessing normal cord tissue within their interstices. $^{2,25,26}$ Besides the cord, these lesions may involve the bony spine, paraspinal tissues, and skin, sharing a common metameric tissue origin., ${ }^{3,27}$
Chiro et $\mathrm{al}^{5}$ based on angiographic morphology (1971). The proposed type IV AVF addition of Heros et $\mathrm{al}^{6}$ (1986); the further subclassification by Gueguen et $\mathrm{al}^{7}{ }^{7}$ of type IV into 3 subtypes based on size and number of arterial feeders; and the proposed subdivision by Spetzler et $\mathrm{al}^{8}$ of type I AVF into subtypes A (single arterial feeder) and B (multiple feeders).

Type I: Spinal Dural AVF. Spinal dural arteriovenous fistulas (SDAVFs) account for 70\% of all SVSs (Fig 2A). ${ }^{3,12}$ Approximately $80 \%$ of SDAVFs are found along the dorsal lower thoracic cord surface between levels T6 and L2. ${ }^{6,8,13}$ Anatomically, an SDAVF is an anomalous intradural communication between a dural artery and radicular vein within the intervertebral foramen without
Type IV: Intradural Perimedullary AVF. The intradural perimedullary AVF (IPAVF) was first described by Djindjian et $\mathrm{al}^{28}$ in 1977 , and later proposed as a type $\mathrm{IV}^{6}$ addition to the 1971 CS of Di Chiro et $\mathrm{al}^{5}$ (Fig 2D). IPAVF prevalence is approximately $8 \%-19 \%$ of SVSs. ${ }^{14}$ The IPAVFs are pial-based lesions supplied by the ASA and/or PSA, sometimes with a small intervening nidus. In 1987, Gueguen et $\mathrm{al}^{7}$ proposed IPAVF types I-III according to the size and number of arterial feeders, now frequently referenced as subtypes IVa, IVb, and IVc.

However, this morphologically based SVS CS is limited in scope because some SVSs remain outside their descriptive criteria. Recent proposals to address this limitation include a location-based CS 
Table 1: Historical spinal vascular shunt classification schemes

\begin{tabular}{|c|c|c|}
\hline Authors & Year & Classification Summary \\
\hline $\begin{array}{l}\text { Di Chiro } \\
\text { et } \mathrm{al}^{5}\end{array}$ & 1971 & $\begin{array}{l}\text { Type I: Single coiled vessel (AVF) } \\
\text { Type II: Glomus type (AVM) } \\
\text { Type III: Juvenile (AVM) }\end{array}$ \\
\hline $\begin{array}{l}\text { Heros } \\
\text { et } \mathrm{al}^{6}\end{array}$ & 1986 & $\begin{array}{l}\text { Type IV: Direct AVF (IPAVF) involving the } \\
\text { intrinsic arterial supply of the cord }\end{array}$ \\
\hline $\begin{array}{l}\text { Gueguen } \\
\text { et } \mathrm{al}^{7}\end{array}$ & 1987 & $\begin{array}{l}3 \text { Types of classification of IPAVF (type IV) } \\
\text { I) Single arterial feeder, small AVF } \\
\text { II) Multiple feeders, medium AVF } \\
\text { III) Multiple feeders, giant AVF }\end{array}$ \\
\hline $\begin{array}{c}\text { Spetzler } \\
\text { et } \mathrm{al}^{8}\end{array}$ & 2002 & $\begin{array}{l}\text { AVF types (and subtypes): } \\
\text { Extradural } \\
\text { Intradural (dorsal or ventral; and single (A) } \\
\quad \text { or multiple (B) feeders) } \\
\text { AVM types (and subtypes): } \\
\text { Extradural-intradural } \\
\text { Intradural (intramedullary, intramedullary- } \\
\quad \text { extramedullary, or conus medullaris) }\end{array}$ \\
\hline $\begin{array}{l}\text { Zozulya } \\
\text { et } \mathrm{al}^{9}\end{array}$ & 2006 & $\begin{array}{l}\text { Type I: Intramedullary } \\
\text { Type II: Intradural or perimedullary } \\
\text { Type III: Dural } \\
\text { Type IV: Epidural } \\
\text { Type V: Intravertebral } \\
\text { Type VI: Combined }\end{array}$ \\
\hline Takai $^{10}$ & 2017 & $\begin{array}{l}\text { Proposed the addition of } \\
\text { Type V: Extradural AVF, with subtypes } \\
\text { Va/Vb: with/without intradural venous } \\
\text { drainage }\end{array}$ \\
\hline
\end{tabular}

Type IV: Intradural Perimedullary AVF. Although the clinical presentation of IPAVF varies with subtype, approximately $93 \%$ of patients present with neurologic deficits, among which $29 \%$ are acute, typically resulting from subarachnoid hemorrhage. $^{15,22}$ A 2013 meta-analysis ${ }^{15}$ consisting of 213 cases found subtype IVa to be more common in males (male/female ratio=1.4:1), with a mean age of 46.9 years. Mean ages for subtypes IVb and IVc were 34.3 and 18.7 years, both without sex predilection.

Syndromic associations with IPAVFs have been reported, including Osler-Weber-Rendu, Proteus, Klippel-Trenaunay, and Down syndromes. ${ }^{3,6,15,22,34-37}$

\section{Imaging Findings}

Type I: Spinal Dural Arteriovenous Fistula. T2-weighted MR imaging depicts serpiginous perimedullary flow voids, typically overlying the dorsal cord and conus, without an intra-

consisting of 6 lesion types proposed by Zozulya et $\mathrm{al}^{9}$ and a type $\mathrm{V}$ extradural AVF proposed by Takai. ${ }^{10}$

\section{Clinical Symptomology}

Type I: Spinal Dural AVF. The typical presentation is an older (range, 55-60 years of age) man (male/female ratio $=5: 1)^{13}$ with a history of nonspecific progressive myelopathic symptoms. The clinical picture is sometimes referred to as Foix-Alajouanine syndrome. ${ }^{4,29}$ Symptoms are related to cord edema and ischemia resulting from arterialized intravenous pressure competing with cord drainage, though venous thrombosis has also been described. ${ }^{30-32}$

Type II: Spinal Glomus AVM. Patients are typically in their secondto-fourth decades of life (mean age, 28 years) without sex predilection. ${ }^{11,23}$ Approximately 50\%-75\% of patients present with acute or subacute symptoms related to subarachnoid hemorrhage or, less commonly, venous thrombosis. $^{23,27}$

Type III: Spinal Juvenile AVM. Although the low frequency of SJAVMs limits available data, the typical presentation age is younger than 15 years, with a slight male predominance (male/ female ratio $=1.7: 1) .{ }^{12,16,26}$ As reported in a 2014 meta-analysis of 51 cases of SJAVM, ${ }^{16}$ the most common presentation was a progressive neurologic deficit in $35 \%$, followed closely by acute hemorrhage (31\%) and an acute neurologic deficit without hemorrhage (22\%). Twelve percent of cases were incidental discoveries. Cobb syndrome refers to the clinical manifestations of SJAVM involving all tissues of the involved metamere. ${ }^{33}$ medullary nidus (Fig 3 and Table 2). Secondary congestive myelopathy is also best-depicted on routine T2-weighted TSE and STIR imaging as nonspecific, hyperintense signal within an expanded cord. ${ }^{38,39}$ Contrast-enhanced T1 fat-suppression MR imaging or CT may show cord enhancement related to chronic venous congestion and compromise of the blood-spinal cord barrier. ${ }^{40}$ The presence of a thin $\mathrm{T} 2$ hypointense rim may be more specific to SDAVFs, possibly due to the presence of deoxyhemoglobin within dilated peripheral capillaries of the distended cord. ${ }^{14,39-41}$

First-pass MRA may depict the involved dural artery communicating with a prominent arterial network along the dural root sleeve at the level of the fistula, with a prominent early filling radicular vein. Multiphase time-resolved MRA depicts progressive enhancement through the same vascular structures and may increase the rate of successful SDAVF localization. ${ }^{42}$

Selective DSA injection of the involved segmental artery shows shunted contrast advancing through the fistulous connection with retrograde reflux into a dilated radicular vein and perimedullary venous network. ${ }^{38,39}$

Type II: Spinal Glomus AVM. The eccentric (not centered) nidus of a SGAVM shows variable enhancement and may be partially or completely intramedullary (Fig 4 and Table 2). ${ }^{14,43}$ Surrounding T2-hyperintensity with regional cord expansion may represent edema, gliosis, and/or ischemia. ${ }^{11,26}$ Subarachnoid or intramedullary signal loss on gradient MR imaging may reflect hemorrhage. ${ }^{26}$ The presence of prominent radicular venous outflow depicted as intra- and perimedullary flow voids on T2weighted MR imaging is variable. ${ }^{44}$ 


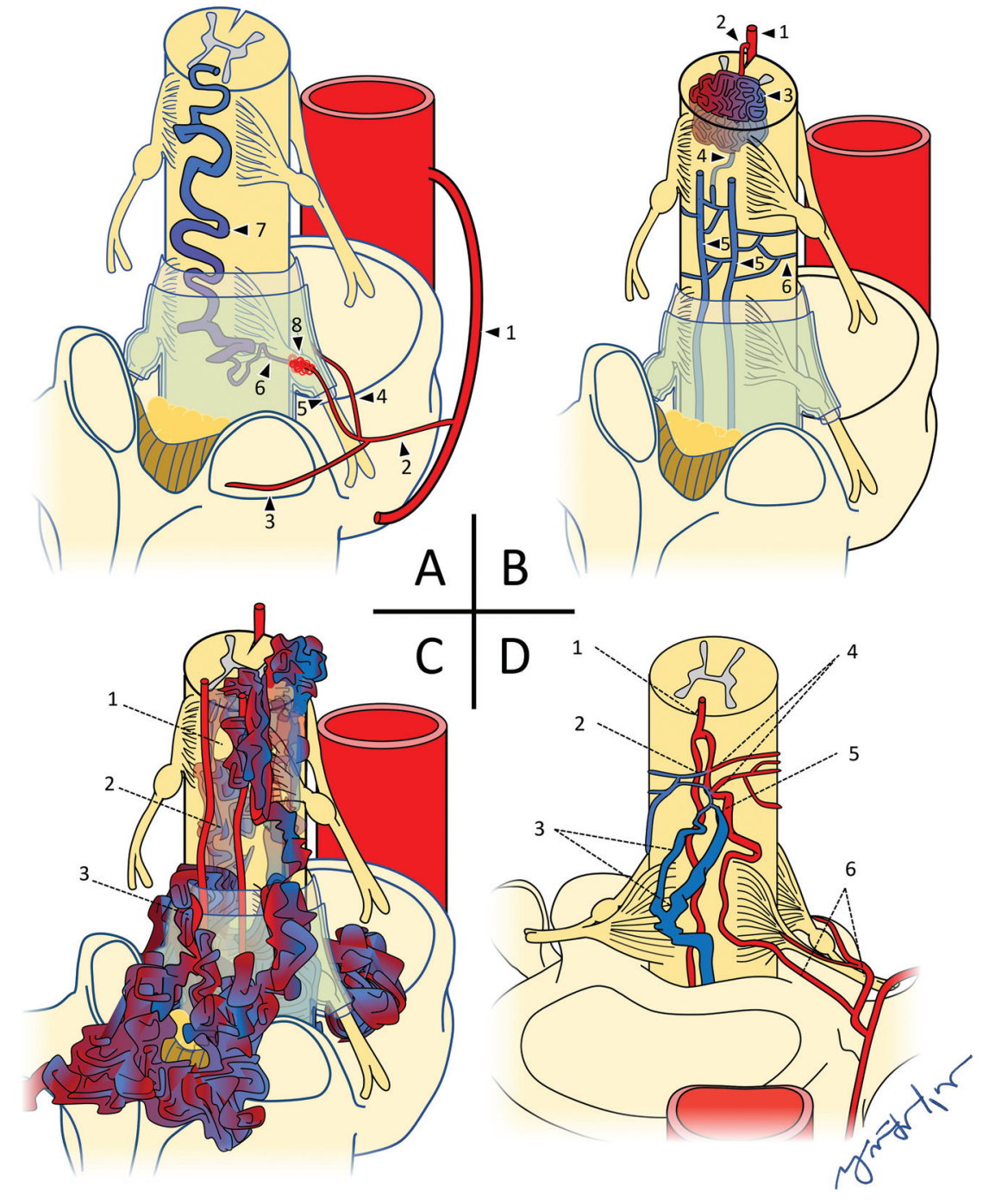

FIG 2. A, Type I spinal dural AVF: 1, Intercostal artery; 2, spinal artery; 3, dorsal/muscular branch; 4, radicular artery, ventral branch; 5 , radicular artery, dorsal branch; 6 , radicular vein; 7, engorged perimedullary vein; 8 , dural AVF. B, Type II spinal glomus AVM: 1, anterior spinal artery; 2 , feeding arterial branch; 3 , intramedullary glomus/nidus; 4 , draining branch to pial venous network; 5 , posterior spinal veins; 6 , pial venous network. C, Type III spinal juvenile/metameric AVM: 1, normal cord tissue within the nidal interstices; 2, intramedullary elements of AVM; 3, extramedullary elements of AVM. D, Type IV IPAVF: 1, anterior spinal artery; 2, fistula; 3, multiple dilated perimedullary veins; 4, multiple contributing arterial feeders; 5 , medullary artery; 6 , ventral and dorsal radicular arteries.

Volume-rendered surface reconstructions from CTA source data permit further assessment of soft-tissue involvement, particularly with regard to the bony spinal elements, and are useful for surgical planning. ${ }^{45}$

Numerous ectactic high-flow intraand extramedullary shunts are typically present with extremely rapid antegrade drainage via the often-dilated perimedullary and epidural venous pathways. ${ }^{45}$

Type IV: Intradural Perimedullary AVF. T2-weighted MR imaging demonstrates prominent perimedullary flow voids typically along the ventral cord surface, in contrast to SDAVFs, which are typically dorsal (Fig 6 and Table 2). Depending on the degree of arterial and venous ectasia, cord compression and displacement may be present. Less consistently, T2 signal hyperintensity reflecting cord edema, ischemia, and/or gliosis may be present, as well as enhancement of the pia arachnoid. $^{35,45}$

The angioarchitectural findings of IPAVFs depicted on CTA or MRA depend on the subtype. Findings of subtype IVa lesions include enhancement of a normal-caliber ASA branch and a mildly dilated perimedullary vein along the ventral surfaces of the conus medullaris or filum terminale. ${ }^{45,46}$

Subtypes IVb and IVc IPAVFs both depict $\geq 1$ arterial feeder and/or shunt, with ectatic perimedullary drainage. Subtype IVc generally has a greater number and size of involved vessels and shunts compared with subtype IVb. ${ }^{46}$ Selective DSA injection may depict this shunt/vessel multiplic-

Selective DSA injections typically show $\geq 1$ feeding branch originating from the ASA, PSA, or vertebral arteries directed toward the intramedullary nidus. Intranidal aneurysms may opacify in up to one-third of cases. Drainage is typically via veins of the coronal and epidural venous plexuses, which may or may not be engorged. ${ }^{44}$

Type III: Metameric Spinal AVM. T2-weighted imaging depicts extensive ectatic intramedullary flow voids with variable involvement of the subarachnoid and epidural spaces, as well as surrounding spinal elements and extraspinal tissues in a metameric distribution (Fig 5 and Table 2). ${ }^{45}$ Parenchymal cord tissue may be visible within the interstices of the nidus. ${ }^{2,25,26}$ Cord compression from the markedly dilated extramedullary vascular architecture is also best-depicted on MR imaging. ${ }^{14}$ ity as an abrupt transition to a larger caliber vessel, with contrast dilution from unopacified converging feeders. ${ }^{47}$ The rate of contrast progression through the vascular elements increases with subtype order. ${ }^{7}$

\section{Differential Diagnoses/Mimics}

CSF Flow Artifacts. Sequences using short-TE, thinner slices, and imaging planes perpendicular to the direction of CSF flow can create signal voids mimicking the vascular flow voids related to shunting (Fig 7A). ${ }^{39}$ Heavily T2-weighted sequences are most likely to distinguish vascular from CSF flow voids. ${ }^{14}$

Tortuous Redundant Roots. Severe thecal sac stenosis can result in tortuous cauda equina roots appearing as serpentine areas of 
perimedullary low signal (Fig $7 B) .{ }^{48}$ The close proximity of these low-signal areas to the level of stenosis can help distinguish this finding from vascular flow voids.

Spinal Vascular Masses. Vascular masses of the cord may exhibit imaging features similar to the those of the nidus of a type II spinal AVM (Fig 8A). ${ }^{13,26,49}$ For example, hemangioblastomas may be accompanied by surrounding cord edema and a dilated draining vein. Distinction is made by lesion multifocality, avid
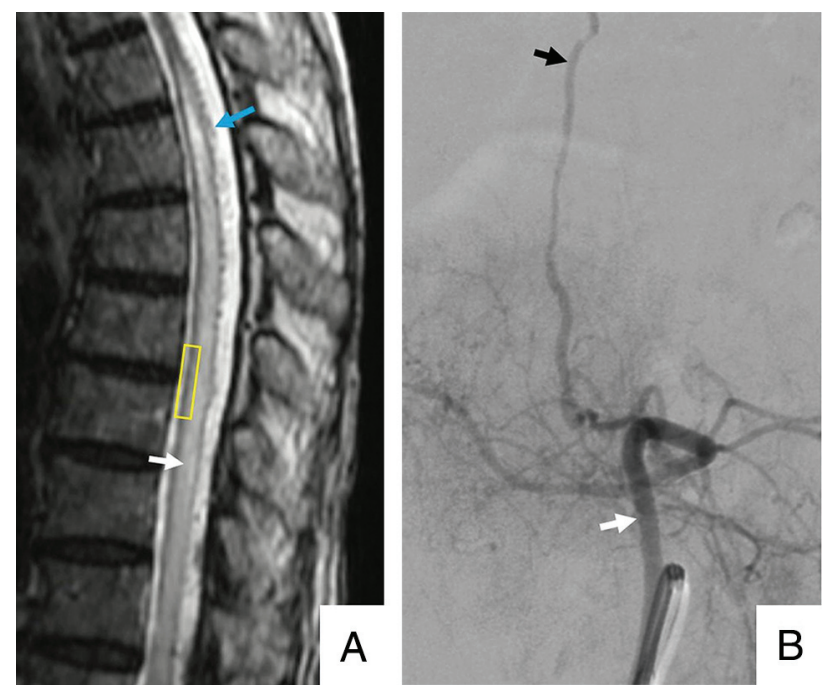

FIG 3. A 79-year-old man with a type I spinal dural AVF. A, Sagittal T2 MR imaging of the thoracic spine shows extensive intramedullary edema as signal hyperintensity (white arrow) throughout the cord. The thin peripheral hypointense rim (yellow rectangle) may reflect deoxyhemoglobin within dilated peripheral capillaries. Serpiginous perimedullary flow voids (blue arrow) are most conspicuous along the dorsal aspect of the thoracic cord. B, Frontal view DSA injection of the left $\mathrm{L} 3$ segmental artery (white arrow) shows early filling of an ectatic spinal vein (black arrow). enhancement, or syndromic associations such as Von HippelLindau disease. $^{26,50}$

Mass effect sometimes imparted by cavernous malformations may result in regional venous engorgement. ${ }^{40}$ However, a thin rim of susceptibility signal loss related to hemosiderin staining, as well as the characteristic "popcorn" signal pattern and the angiographically occult nature, may distinguish a cavernous malformation from a type II spinal AVM. ${ }^{13,51}$

Collateral Venous Flow. Obstructive pathologies compromising normal venous drainage with resulting collateral venous engorgement may be difficult to distinguish from the vascular prominence of SVS types lacking an intervening nidus. ${ }^{52}$ Recognizing characteristic patterns of collateral venous engorgement and identifying a source of obstruction can help distinguish this process from an SVS.

\section{Management}

Type I: Dural AVF. Operative management involves ligation of the fistulized vein through a laminectomy. ${ }^{21}$ Endovascular management typically involves cannulation of the involved segmental artery followed by embolization of the fistula and draining vein.

Type II: Glomus AVM. Although the technique varies with lesion location and operator preferences, multilevel laminectomies typically afford sufficient lesion access ${ }^{23,53}$ for microsurgical resection of extramedullary SGAVM elements. Presurgical embolization may achieve partial lesion obliteration and facilitate intraoperative localization via casting of the embolic material. ${ }^{23,53}$

Stereotactic radiosurgery is an emerging treatment strategy, with 2 single-center studies demonstrating rates of lesion-size reduction between $50 \%$ and $100 \%$, with complete obliteration rates up to $19 \%{ }^{17,54}$

Table 2: Imaging findings of spinal vascular shunts types I-IV

\begin{tabular}{|c|c|c|c|}
\hline Shunt Type & MRI & CTA/MRA & DSA \\
\hline I (SDAVF) & $\begin{array}{l}\text { T2 bright cord edema, } \pm \text { thin } \mathrm{T} 2 \text { dark rim } \\
\text { Cord expansion } \\
\text { Prominent dorsal perimedullary flow voids }\end{array}$ & $\begin{array}{l}\text { May localize the involved dural } \\
\text { artery along dorsal dural root } \\
\text { sleeve } \\
\text { Prominent draining medullary vein }\end{array}$ & $\begin{array}{l}\text { Definitive shunt localization } \\
\text { Spinal arterial stasis in setting of } \\
\text { cord edema }\end{array}$ \\
\hline II (SGAVM) & $\begin{array}{l}\text { Eccentric intramedullary flow voids of nidus } \\
\text { on T2WI } \\
\text { T2 bright cord edema } \\
\text { Cord expansion } \\
\pm \text { Prominent perimedullary flow voids }\end{array}$ & $\begin{array}{l}\text { Heterogeneous nidal enhancement } \\
\text { May depict multiplicity of arterial } \\
\text { feeders }\end{array}$ & $\begin{array}{l}\text { Delineation of arterial feeders } \\
\text { Aneurysms in one-third of cases } \\
\pm \text { Engorged perimedullary veins }\end{array}$ \\
\hline III (SJAVM) & $\begin{array}{l}\text { Extensive, ectatic flow voids may involve } \\
\text { any tissues of a single metamere } \\
\text { Normal cord tissue within nidal interstices } \\
\pm \text { Cord compression from large vascular } \\
\text { structures }\end{array}$ & $\begin{array}{l}\text { Variable enhancement of the } \\
\text { extensively involved vascular } \\
\text { structures }\end{array}$ & $\begin{array}{l}\text { Numerous ectatic high-flow intra- } \\
\text { and extramedullary shunts } \\
\text { Rapid antegrade drainage via intra-, } \\
\text { or extramedullary venous } \\
\text { structures }\end{array}$ \\
\hline IV (IPAVF) & $\begin{array}{l}\text { Prominent ventral perimedullary flow voids } \\
\text { on T2 MR imaging } \\
\pm \text { Cord compression from perimedullary } \\
\text { venous ectasia } \\
\pm \text { Cord edema/expansion on T2 MR } \\
\text { imaging }\end{array}$ & $\begin{array}{l}\geq 1 \text { arterial feeder and draining } \\
\quad \text { veins of variable size based on } \\
\text { subtype } \\
\pm \text { Pia arachnoid enhancement }\end{array}$ & $\begin{array}{l}\text { Progressively increasing rates of } \\
\text { flow with subtypes IVa-c } \\
\text { May depict dilation of small pial } \\
\text { surface arteries or venous } \\
\text { aneurysms }\end{array}$ \\
\hline
\end{tabular}



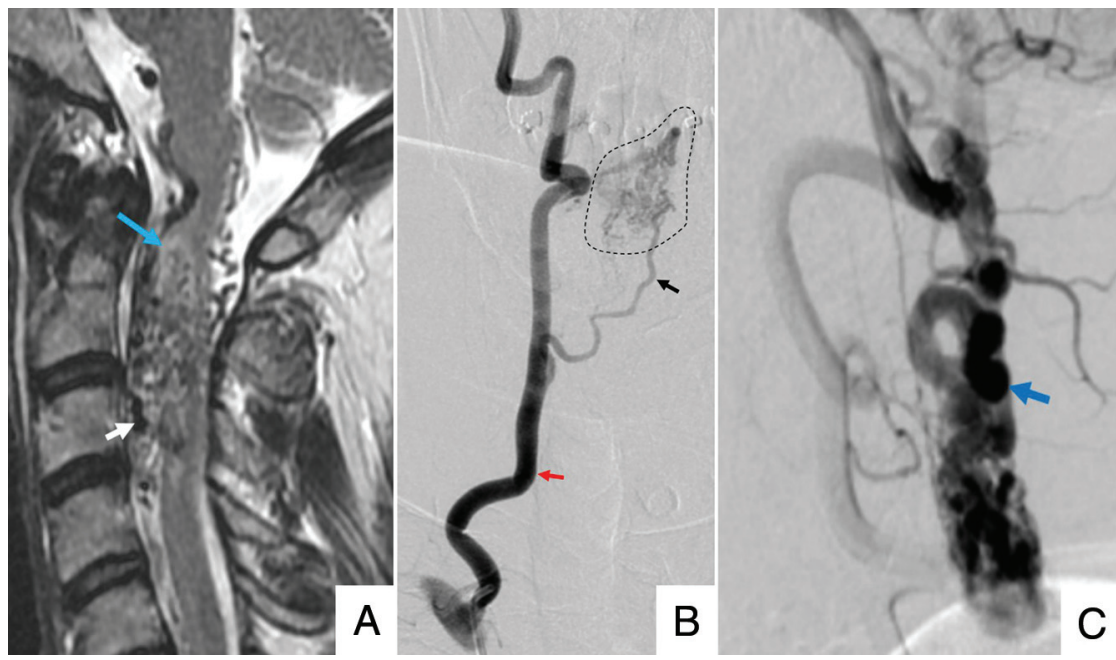

FIG 4. A 45-year-old man with a type II spinal glomus AVM. A, Sagittal T2 MR imaging of the cervical spine shows serpiginous intramedullary and perimedullary flow voids (white arrow), with adjacent cord hyperintensity (blue arrow). B. Frontal view DSA injection of the right vertebral artery (red arrow) shows opacification of a feeding arterial branch (black arrow) and nidal elements (dashed outline). C, Lateral view DSA shows early filling of ectatic perimedullary veins (blue arrow). generally regarded as first-line therapy for SJAVMs due to high rates of intraoperative hemorrhage.

Type IV: Intradural Perimedullary AVF. The treatment approach depends on the number and size of the involved arterial feeders and thus the IPAVF subtype. Therapy generally consists of endovascular embolization, surgery, or a combination of both.

\section{CONCLUSIONS}

The relatively infrequent and anatomically complex nature of spinal vascular shunts can present diagnostic and therapeutic challenges to radiologic and surgical teams. Assessment of these lesions can be further complicated by the lack of a universally accepted classification scheme. However, a working knowledge of the 4 most frequently described types of spinal vascular
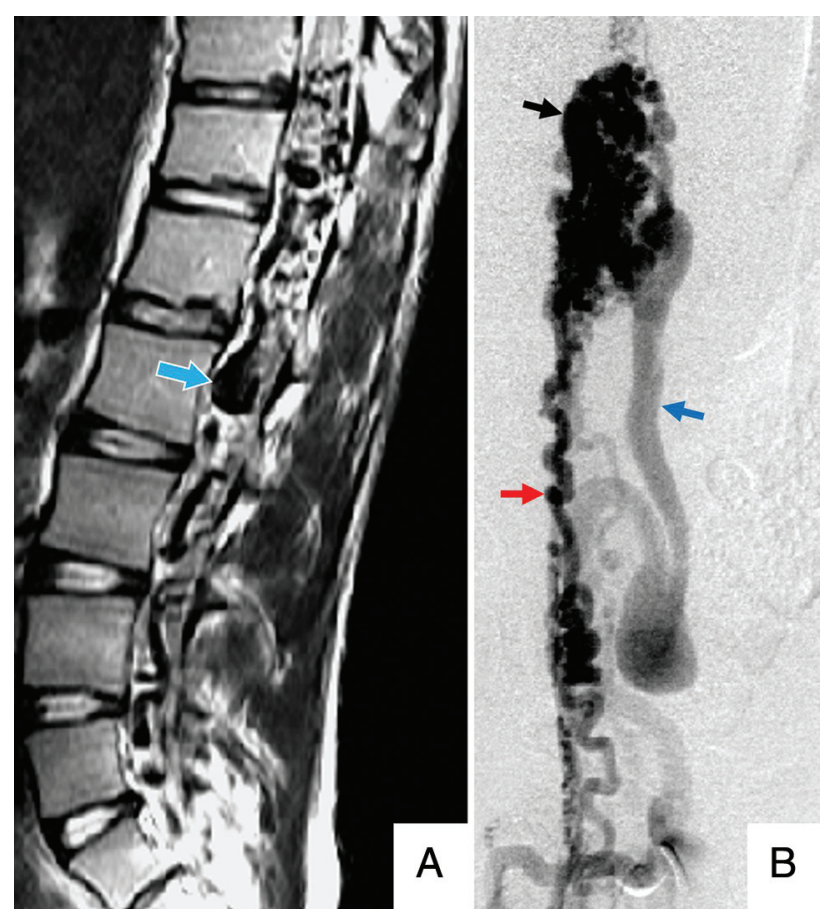

FIG 5. A 14-year-old girl with a type III spinal juvenile/metameric AVM. A, Sagittal T2 MR imaging of the lumbar spine shows numerous ectatic perimedullary and intramedullary flow voids (blue/white arrow). B. Frontal view DSA injection of the right L2 lumbar artery shows opacification of a prominent anterior spinal artery (red arrow), intramedullary and extramedullary nidal elements (black arrow), and early filing of an ectatic perimedullary vein (blue arrow).

Type III: Spinal Juvenile AVM. SJAVMs are not frequently amenable to intervention, and benefits are often brief, with high rates of additional procedures required. ${ }^{1,26,34}$ When attempted, embolization is shunts permits a useful initial evaluation of these lesions. Imaging is critical, and radiologists play a pivotal role in suggesting a diagnosis and planning selective treatment options. Early diagnosis improves outcomes, because patients may benefit from early intervention.

\section{REFERENCES}

1. Bao Y, Ling F. Classification and therapeutic modalities of spinal vascular malformations in 80 patients. Neurosurgery 1997;40:75-81 CrossRef Medline

2. Singh R, Lucke-Wold B, Gyure K, et al. A review of vascular abnormalities of the spine. Ann Vasc Med Res2016;3:1045 Medline

3. Endo T, Endo H, Sato K, et al. Surgical and endovascular treatment for spinal arteriovenous malformations. Neurol Med Chir (Tokyo) 2016;56:457-64 CrossRef Medline

4. Flores BC, Klinger DR, White JA, et al. Spinal vascular malformations: treatment strategies and outcome. Neurosurg Rev 2017;40:15-28 CrossRef Medline

5. Di Chiro GJ, Doppman L, Ommaya AK. Radiology of spinal cord arteriovenous malformations. In: Di Chiro GJ, Doppman L, Ommaya AK. Progress in Neurological Surgery. Karger Publishers; 1971;4:329-54 CrossRef

6. Heros RC, Debrun GM, Ojemann RG, et al. Direct spinal arteriovenous fistula: a new type of spinal AVM. J Neurosurg 1986;64:134-39 CrossRef Medline

7. Gueguen B, Merland JJ, Riche MC, et al. Vascular malformations of the spinal cord: intrathecal perimedullary arteriovenous fistulas fed by medullary arteries. Neurology 1987;37:969-79 CrossRef Medline

8. Spetzler RF, Detwiler PW, Riina HA, et al. Modified classification of spinal cord vascular lesions. J Neurosurg 2002;96:145-56 CrossRef Medline

9. Zozulya YP, Slin'ko EI, Al-Qashqish II. Spinal arteriovenous malformations: new classification and surgical treatment. Neurosurg Focus 2006;20: E7 CrossRef Medline

10. Takai K. Spinal arteriovenous shunts: angioarchitecture and historical changes in classification. Neurol Med Chir (Tokyo) 2017;57:356-65 CrossRef Medline 

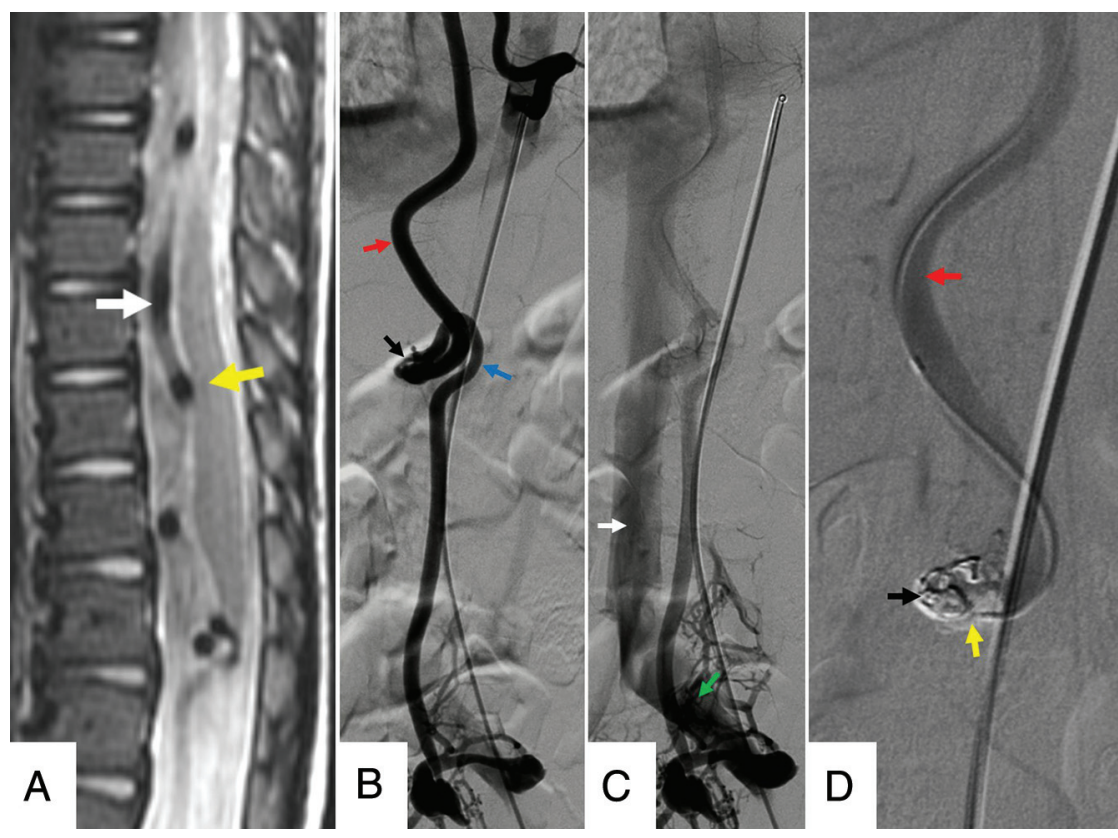

FIG 6. An 11-year-old boy with a type IV intradural-perimedullary spinal AVF. A, Sagittal T2 MR imaging of the thoracic spine shows enlarged, predominantly ventral, perimedullary flow voids (white arrow) indenting the ventral cord (yellow arrow). B and C, Sequential frontal view DSA images from injection of the left T9 segmental artery show contrast progression through the ASA (red arrow), nidus (black arrow), ectatic left radiculomedullary vein (blue arrow), left common iliac vein (green arrow), and inferior vena cava (white arrow). D, Frontal magnified DSA shows a catheter traversing the opacified ASA (red arrow) and embolization coil (black arrow) and Onyx (Covidien) (yellow arrow) material within the nidus. The draining vein no longer opacifies as a result of shunt obliteration.
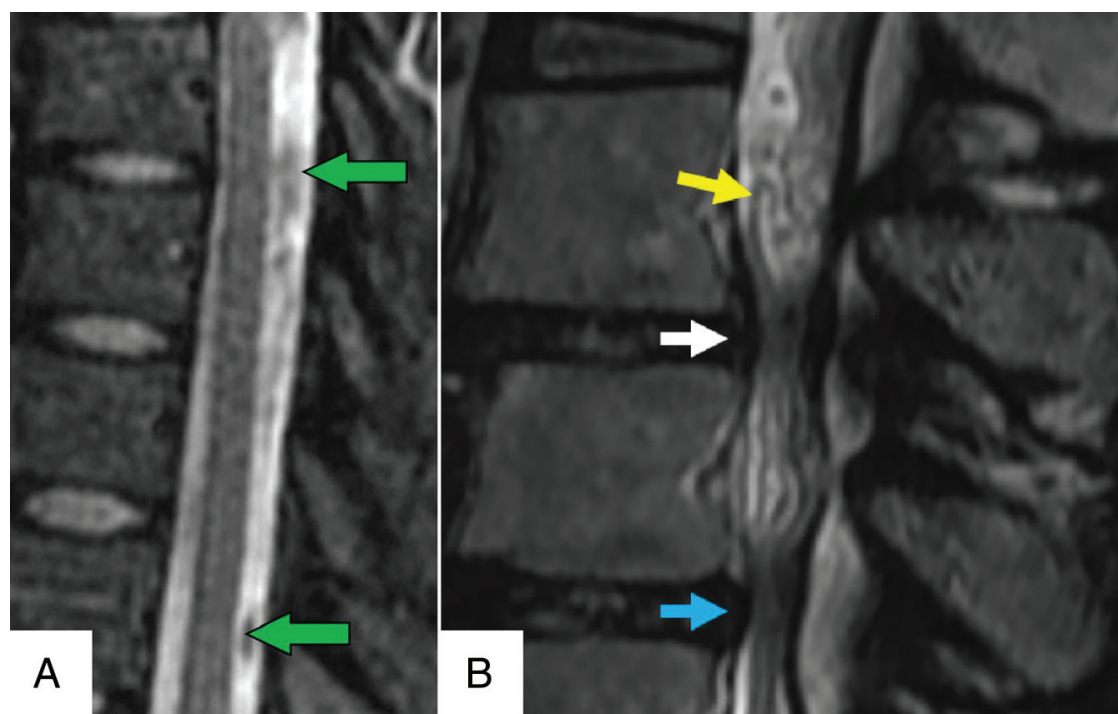

FIG 7. A, A 41-year-old woman with normal CSF flow-related signal voids. Sagittal T2 MR imaging of the thoracic spine shows multiple prominent CSF flow voids (green arrows), mimicking the perimedullary vascular flow voids characteristic of spinal vascular shunts. $B$, A 71-year-old man with spinal stenosis. Sagittal T2 MR imaging of the lumbar spine shows multiple tortuous, redundant-appearing cauda equina nerve roots (yellow arrow) mimicking the perimedullary flow voids of a spinal vascular shunt above the levels of thecal sac stenoses (white and blue arrows).
11. Krings T, Mull M, Gilsbach JM, et al. Spinal vascular malformations. Eur Radiol 2005;15:267-78 CrossRef Medline

12. Ferch RD, Morgan MK, Sears WR. Spinal arteriovenous malformations: a review with case illustrations. $J$ Clin Neurosci 2001;8:299-304 CrossRef Medline

13. Krings T, Geibprasert S. Spinal dural arteriovenous fistulas. AJNR Am J Neuroradiol 2009;30:639-48 CrossRef Medline

14. Higano S. Magnetic resonance imaging of spinal vascular lesions. Neurovascular Imaging. London: Springer; 2011:487505

15. Gross BA, Du R. Spinal pial (type IV) arteriovenous fistulae: a systematic pooled analysis of demographics, hemorrhage risk, and treatment results. Neurosurgery 2013;73:141-51 CrossRef Medline

16. Gross BA, Du R. Spinal juvenile (type III) extradural-intradural arteriovenous malformations. J Neurosurg Spine 2014;20:452-58 CrossRef Medline

17. Kalani MA, Choudhri O, Gibbs IC, et al. Stereotactic radiosurgery for intramedullary spinal arteriovenous malformations. J Clin Neurosci 2016;29:162-67 CrossRef Medline

18. Singh B, Behari S, Jaiswal AK, et al. Spinal arteriovenous malformations: is surgery indicated? Asian J Neurosurg 2016;11:134 CrossRef

19. Eddleman CS, Jeong H, Cashen TA, et al. Advanced noninvasive imaging of spinal vascular malformations. Neurosurg Focus 2009;26:E9 CrossRef Medline

20. Sorenson T, Giordan E, Cannizzaro D, et al. Surgical ligation of spinal dural arteriovenous fistula. Acta Neurochir (Wien) 2018;160:191-94 CrossRef Medline

21. Goyal A, Cesare J, Lu VM, et al. Outcomes following surgical versus endovascular treatment of spinal dural arteriovenous fistula: a systematic review and meta-analysis. J Neurol Neurosurg Psychiatry 2019;90:1139-46 CrossRef Medline

22. Mourier KL, Gobin YP, George B, et al. Intradural perimedullary arteriovenous fistulae: results of surgical and endovascular treatment in a series of 35 cases. Neurosurgery 1993;32:885-91 CrossRef Medline

23. Connolly E Jr, Zubay GP, McCormick PC, et al. The posterior approach to a series of glomus (type II) intramedullary spinal cord arteriovenous malformations. Neurosurgery 1998;42:774-84 CrossRef Medline

24. Samonenko YM, Shchehlov DV, Sviridyuk OE, et al. Endovascular and microsurgical treatment for spinal arteriovenous malformations: 

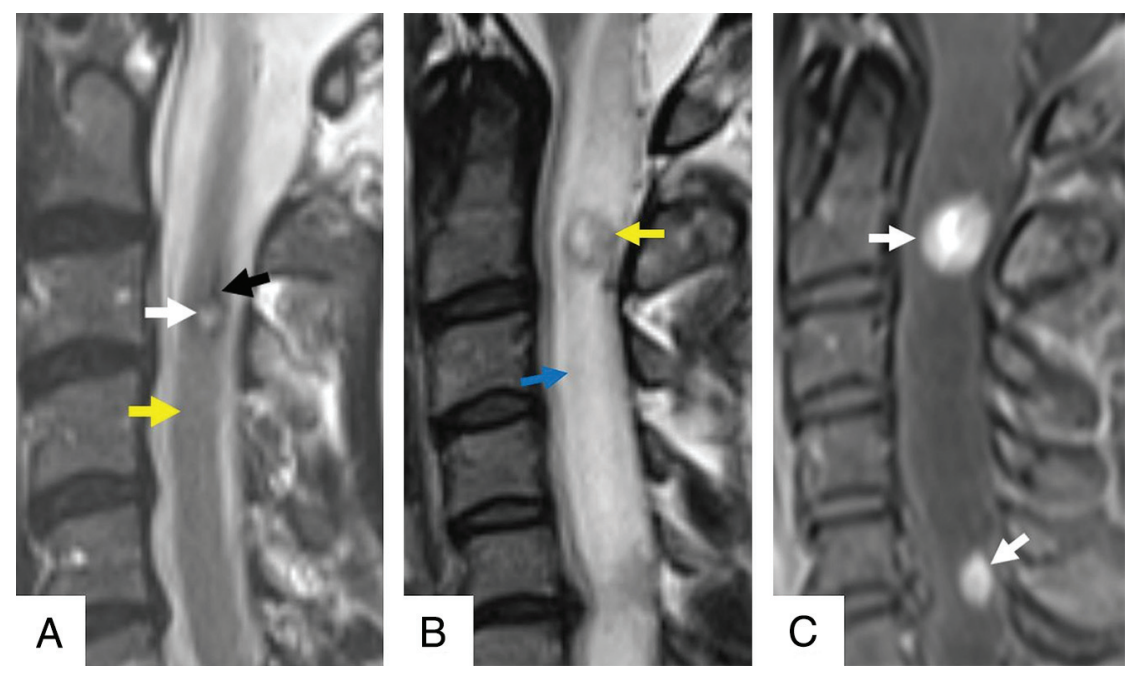

35. Antonietti L, Sheth SA, Halbach VV, et al. Long-term outcome in the repair of spinal cord perimedullary arteriovenous fistulas. $A J N R$ Am J Neuroradiol 2010;31:1824-30 CrossRef Medline

36. Cullen S, Alvarez H, Rodesch G, et al. Spinal arteriovenous shunts presenting before 2 years of age: analysis of 13 cases. Childs Nerv Syst 2006;22:1103-10 CrossRef Medline

37. Rohany M, Shaibani A, Arafat O, et al. Spinal arteriovenous malformations associated with KlippelTrenaunay-Weber syndrome: a literature search and report of two cases. AJNR Am J Neuroradiol 2007;28:584-89 Medline

38. Kular S, Tse G, Budu A, et al. Transarterial CT angiography for surgical planning of spinal dural arteriovenous fistula. $\mathrm{Br} J$ Radiol 2020;93:20200020 CrossRef Medline

ming of the cervical spine shows a small intramedullary mass with central hyperintense signa (white arrow) and a peripheral rim of low signal (black arrow), indicative of blood products in various stages of degradation. There is normal signal in the adjacent cord (yellow arrow). B, A 42year-old woman with a history of Von Hippel-Lindau disease and cervical cord hemangioblastomas. Sagittal T2 MR imaging shows a small intramedullary mass (yellow arrow) with heterogeneous hyperintense internal signal and surrounding cord edema with cord expansion (blue arrow). C, Sagittal contrast-enhanced $\mathrm{T} 7$ with fat saturation depicts intense enhancement (white arrows) within multiple lesions.

39. Jeng $Y$, Chen DY, Hsu HL, et al. Spinal dural arteriovenous fistula: imaging features and its mimics. Korean J Radiol 2015;16:1119-31 CrossRef Medline

40. Krings T. Vascular malformations of the spine and spinal cord. Clin Neuroradiol 2010;20:5-24 CrossRef Medline

41. Hurst RW, Grossman RI. Peripheral

our experience. Endovasc Neuroradiol 2019;27:32-40 CrossRef

25. Rosenblum B, Oldfield EH, Doppman JL, et al. Spinal arteriovenous malformations: a comparison of dural arteriovenous fistulas and intradural AVM's in 81 patients. J Neurosurg 1987;67:795-802 CrossRef Medline

26. Do-Dai DD, Brooks MK, Goldkamp A, et al. Magnetic resonance imaging of intramedullary spinal cord lesions: a pictorial review. Curr Probl Diagn Radiology 2010;39:160-85 CrossRef Medline

27. Niimi $Y$, Berenstein A, Setton A, et al. Embolization of spinal dural arteriovenous fistulae: results and follow-up. Neurosurgery 1997;40:67583 CrossRef Medline

28. Djindjian M, Djindjian R, Rey A, et al. Intradural extramedullary spinal arterio-venous malformations fed by the anterior spinal artery. Surg Neurol 1977;8:85-93 Medline

29. Wyburn-Mason R. The Vascular Abnormalities and Tumours of the Spinal Cord and Its Membranes. Henry Kimpton; 1943

30. Shinoyama M, Endo T, Takahash T, et al. Long-term outcome of cervical and thoracolumbar dural arteriovenous fistulas with emphasis on sensory disturbance and neuropathic pain. World Neurosurg 2010;73:401-08 CrossRef Medline

31. Sasamori T, Hida K, Yano S, et al. Long-term outcomes after surgical and endovascular treatment of spinal dural arteriovenous fistulae. Eur Spine J 2016;25:748-54 CrossRef Medline

32. Criscuolo GR, Oldfield EH, Doppman JL. Reversible acute and subacute myelopathy in patients with dural arteriovenous fistulas: FoixAlajouanine syndrome reconsidered. J Neurosurg 1989;70:354-59 CrossRef Medline

33. Cobb S. Haemangioma of the spinal cord: associated with skin naevi of the same metamere. Ann Surg 1915;62:641-49 CrossRef Medline

34. Rubin MN, Rabinstein AR. Vascular diseases of the spinal cord. Neurol Clin 2013;31:153-81 CrossRef Medline spinal cord hypointensity on T2-weighted MR images: a reliable imaging sign of venous hypertensive myelopathy. AJNR Am J Neuroradiol 2000;21:781-86 Medline

42. Mathur S, Bharatha A, Huynh TJ, et al. Comparison of time-resolved and first-pass contrast-enhanced $M R$ angiography in pretherapeutic evaluation of spinal dural arteriovenous fistulas. AJNR Am J Neuroradiol 2017;38:206-12 CrossRef Medline

43. Boo S, Hartel J, Hogg JP. Vascular abnormalities of the spine: an imaging review. Curr Probl Diagn Radiol 2010;39:110-17 CrossRef Medline

44. Lee YJ, Terbrugge KG, Saliou G, et al. Clinical features and outcomes of spinal cord arteriovenous malformations: comparison between nidus and fistulous types. Stroke 2014;45:2606-12 CrossRef Medline

45. Vuong SM, Jeong WJ, Morales H, et al. Vascular diseases of the spinal cord: infarction, hemorrhage, and venous congestive myelopathy. Semin Ultrasound CT MR 2016;37:466-81 CrossRef Medline

46. Patsalides A, Knopman J, Santillan A, et al. Endovascular treatment of spinal arteriovenous lesions: beyond the dural fistula. AJNR Am J Neuroradiol 2011;32:798-808 CrossRef Medline

47. Ricolfi F, Gobin PY, Aymard A, et al. Giant perimedullary arteriovenous fistulas of the spine: clinical and radiologic features and endovascular treatment. AJNR Am J Neuroradiol 1997;18:677-87 Medline

48. Schizas C, Theumann N, Burn A, et al. Qualitative grading of severity of lumbar spinal stenosis based on the morphology of the dural sac on magnetic resonance images. Spine (Phila Pa 1976) 2010;35:191924 CrossRef Medline

49. Thron A, Mull M, Reith W. Spinal arteriovenous malformations. Radiologe 2001;41:949-54 CrossRef Medline

50. Koeller KK, Rosenblum RS, Morrison AL. Neoplasms of the spinal cord and filum terminale: radiologic-pathologic correlation. Radiographics 2000;20:1721-49 CrossRef Medline 
51. Hegde AN, Mohan S, Lim CC. Cavernous haemangioma:“popcorn” in the brain and spinal cord. Clin Radiology 2012;67:380-88 CrossRef Medline

52. Marini TJ, Chughtai K, Nuffer Z, et al. Blood finds a way: pictorial review of thoracic collateral vessels. Insights Imaging 2019;10:63-68 CrossRef Medline
53. Velat GJ, Chang SW, Abla AA, et al. Microsurgical management of glomus spinal arteriovenous malformations: pial resection technique. J Neurosurg Spine 2012;16:523-31 CrossRef Medline

54. Hida K, Shirato $\mathrm{H}$, Isu $\mathrm{T}$, et al. Focal fractionated radiotherapy for intramedullary spinal arteriovenous malformations: 10-year experience. J Neurosurg 2003;99:34-38 Medline 